1. Consultant Physician,

Teaching Hospital, DG Khan

2. Assistant Professor Medicine,

DG Khan Medical College, DG Khan

3. Senior Registrar Endocrinology,

Services Hospital, Lahore,

4. Assistant Professor

DG Khan Medical College, DG Khan

5. MO Teaching Hospital, DG Khan

Correspondence Address:

Dr. Sajid Hussain

Consultant Physician,

Teaching Hospital, DG Khan

sajidsajidelahi@yahoo.com

Article received on:

31/07/2015

Accepted for publication:

10/12/2015

Received after proof reading:

09/02/2016

\title{
PEG TUBE; \\ PROPHYLAXIS OF PEG TUBE SITE INFECTION, COMPARISON OF EFFICACY OF CEPHALEXIN AND CO-AMOXICLAV
}

\begin{abstract}
Dr. Sajid Hussain', Dr. Kashif Ali ${ }^{2}$, Dr. Hafiz Muhammad Farhan Rashid ${ }^{3}$, Dr. Abrar Hussain Khosa ${ }^{4}$,
\end{abstract} Dr. Aushter Abbas ${ }^{5}$

ABSTRACRT... Objectives: To determine the efficacy of Cephalexin and Co-amoxiclave in preventing Peristomal infection after PEG tube placement in head and neck and other cancer patients. Study Design: Prospective, randomized clinical trial. Setting: Internal Medicine Department Shaukat Khanum Memorial Cancer Hospital and Research Centre, Lahore. Period: February 2009 to September 2009. Material and Methods: A total of 160 patients including both males and females were selected by Non probability purposive sampling. Patients meeting inclusion and exclusion criteria were registered in the study from outpatient department after informed consent. These patients were randomly assigned into two groups. Group A was started on Cephalexin 500mg q6h Per-orally started $24 \mathrm{hrs}$ before the procedure with the $4^{\text {th }}$ dose given one hour before the procedure and continued it as q6h for five days after the procedure. Group B was given Co-amoxiclav 1G Per-orally $12 \mathrm{hrs}$ before the procedure with the second dose of $1 \mathrm{G}$, one hour before the procedure and then same dose advised $\mathrm{q} 12 \mathrm{~h}$ for five days after PEG tube placement. Results: Male to female ratio in both groups was 2:1 with $63.3 \%$ males and $33.8 \%$ females. Patients were aged between 19-80years, divided in four age groups with $38.8 \%$ falling in age group $50-64$ years. Mean age is $52.11+-13.59$ years and median age 54 years. The efficacy of Cephalexin and Co-amoxiclave was $84.7 \%$ and $78.6 \%$ respectively with no significant statistical difference among two groups. Conclusion: We concluded that Cephalexin and Co-amoxiclave were both equally effective in preventing peristomal infection.

Key words: $\quad$ Peri-stomal infection, Antibiotic Efficacy, Antibiotic prophylaxis.

Article Citation: Hussain S, Ali K, Rashid HMF, Khosa AH, Abbas A. PEG Tube; Prophylaxis of PEG tube site infection, comparison of efficacy of cephalexin and co-amoxiclav. Professional Med J 2016;23(2):187-192. DOI: 10.17957/ $\mathrm{TPMJ} / 16.3038$

\section{INTRODUCTION}

The most common method of maintaining nutritional intake in patients unable to swallow is through a nasogastric tube using one of the commercially available fully supplemented enteral feeds. While preferable to parenteral feeding a number of well documented complications are associated with nasogastric feeding. ${ }^{1}$ Enteral access must be obtained for tube feeding to begin. Temporary access can be achieved with a nasogastric or naso-enteral (small bowel) feeding tube. These tubes are easily placed at the bedside and can also be easily removed. Unfortunately, they often fail secondary to clogging or inadvertent dislodgement and do not provide a secure access route for the provision of calories, medications, or fluids. ${ }^{2}$ More permanent enteral access can be obtained either endoscopically, surgically or with interventional radiology, resulting in either a gastrostomy or jejunostomy. Percutaneous endoscopic gastrostomy (PEG) has developed into a common procedure to obtain gastric access; accounting for approximately 200,000 procedures per year in the United States. Operative gastrostomy remains the most commonly used technique although the procedure is associated with significant morbidity and occasional mortality. The procedure is generally considered safe with the procedure related complications of between $1-2 \% .^{3}$ Survival at one month is a commonly reported endpoint in PEG studies. A 30 day mortality rate may reach up to $6 \%$ depending upon the serious co morbidities, natural history of the disease and difficulty in selecting appropriate patients. ${ }^{4}$ The commonest complication after PEG insertion is peristomal 
infection or wound sepsis with infection rates varying from $3 \%$ to $30 \% .^{5}$ Other complications include peritonitis, septicemia, hemorrhage, tube dislodgement, aspiration, perforation and gastro colic fistula. ${ }^{6,7}$

To prevent these infectious complications antibiotic prophylaxis has been among the recommendations of British society of gastroenterology since $2001^{8}$. Patients with malignant conditions (for example head and neck cancers) are usually immunocompromised and have chances of developing more infections as compared to healthy individuals. ${ }^{9}$ There is evidence that antibiotic prophylaxis at the time of PEG insertion decreases post procedure infection rate from $18 \%$ in placebo group to $3 \%$ taking antibiotics in those who are immunocompromised or have malignant diseases. . $^{9,10}$

There is limited data available in Pakistan to compare the efficacy of antibiotics in prophylaxis of $\mathrm{PEG}^{7}$, so this study was conducted at Shaukat Khanum Memorial Cancer Hospital and Research Centre Lahore (SKMCH\&RC) to asses these findings in patients with head, neck cancers, stroke or having other malignancies. Although both cephalexin and co-amoxiclav are effective in preventing the skin and soft tissue infections ${ }^{11}$, but studies showing comparison between these two are very few. To introduce more efficacious antibiotics for the prevention of Peristomal infection this study was conducted.

\section{MATERIALS AND METHODS}

This study was a prospective, randomized clinical trial conducted at Internal Medicine Department SKMCH\&RC Lahore, Pakistan. Study Duration was 8 months. Study extended for further two months to complete the calculated sample size. A total of 160 patients were selected by Non probability purposive sampling with $10 \%$ margin of error. Patients were divided in two groups with 80 patients in each group, Group A was labeled as Cephalexin group and Group B was labeled as Co-amoxiclav group. $80 \%$ power of the study taking expected percentage of efficacy of Cephalexin i.e. $83.6 \%$ and Co-amoxiclav i.e. $65 \%$ in patients with PEG tube placement. Antibiotic Efficacy was assessed in terms of prevention of peri stomal infection, which is absence of local erythema/tenderness, fever, purulent discharge and raised total leukocyte count in the presence of above over a period of one week. The patients were then followed up for any signs of infection with the variables like Presence or absence of Peri-PEG erythema/tenderness, Fever (pyrexia $>$ 38.5c), Purulent discharge and Raised TLC counts. All data was processed and analyzed using SPSS 12 for windows. Descriptive statistics were calculated. Outcomes were measured as the comparative measure of efficacy of both antibiotics in preventing peristomal infection. Chi square test was used for the comparison between the two groups. P value less than or equal to 0.05 was considered as significant.

Peristomal infection was assessed by clinical assessment in terms of presence of local peri-PEG erythema/ tenderness, purulent discharge, fever and raised total leukocyte count on laboratory investigation on follow up visits. All patients coming for PEG with age > 18 years (either with dysphagia, prophylactic PEG insertion before radiation to head and neck tumors or any other neurological conditions). Patients who received either Cephalexin or Co-amoxiclav 24 hrs before PEG tube insertion.

\section{RESULTS}

Regarding variables of efficacy measurement of antibiotics, Peri PEG erythema and tenderness was absent in 59 (79.7\%) and 76 (90.5\%) patients in Group A and B respectively on Day 1, while this result was 60 (83.3\%) and 62 (86.1\%) on Day 3 and day 7 respectively for Group A, while 71 (83.5\%) on same days for Group B (Table-I). Both antibiotics were equally effective as there was no statistically significant difference ( $p$ value $>0.05$ ).

Purulent discharge was present in 7 patients in group A and 8 patients in Group B on D7, While 5 patients in each group on day 3 and no purulent discharge noted on day 1 in each group (TableII). 
Most of the patients were afebrile on day 1 , in each group, while 9 (12.7\%) and 14 (16.7\%) patients were febrile (with temp.> 38.5c) on day 3 in group $A$ and $B$ respectively. Only 8 patients in group A (11.1\%/) and B (9.5\%) were having significant temperature on day 7 . Overall 140 $(90.3 \%)$ were having no significant temperature in both groups in all three days (Table-III).

We also measured the TLC (total leucocytes count) on different occasions to assess the presence or absence of infection. Counts were in normal ranges in most of the patients on day 1. On day 3 TLC was disturbed (either $>11000 / \mathrm{mcl}$ or $<4000 / \mathrm{mcl})$ in $10(14.3 \%)$ patients in group $A$ and $10(11.6 \%)$ patients in Group B. While On day 7 11(15.3\%) patients had disturbed TLC in Group A and 10 (11.9\%) patients in Group B respectively (Table-IV).

The overall efficacy of antibiotics was measured on basis of above mentioned variables. Cephalexin i.e. group A was efficacious in 61 (84.7\%) patients, while Co-amoxiclav i.e. group $B$ was efficacious in 127 (81.4\%). 11 patients in group $A$ and 18 patients in group $B$ failed to respond to antibiotics (Table-V).

There was no significant difference between the efficacy of two antibiotics in prophylaxis of PEG Tube site infection ( $p$ value 0.325) (Figure-l).

\begin{tabular}{|c|c|c|c|c|c|c|}
\hline \multirow{3}{*}{$\begin{array}{c}\begin{array}{c}\text { Peri-PEG } \\
\text { Erythema/ } \\
\text { tenderness }\end{array} \\
\text { Day-1 } \\
\text { Present } \\
\text { Absent }\end{array}$} & \multicolumn{2}{|c|}{ Group A } & \multicolumn{2}{|c|}{ Group B } & \multicolumn{2}{|c|}{ Group B } \\
\hline & \multicolumn{2}{|c|}{$\mathbf{N} \quad \%$} & \multicolumn{2}{|c|}{$\mathbf{N} \quad \%$} & \multicolumn{2}{|c|}{$\mathbf{N} \quad \%$} \\
\hline & $\begin{array}{l}13 \\
59\end{array}$ & $\begin{array}{l}17.6 \\
79.7\end{array}$ & $\begin{array}{l}08 \\
76\end{array}$ & $\begin{array}{l}09.5 \\
90.5\end{array}$ & $\begin{array}{c}21 \\
135\end{array}$ & $\begin{array}{l}13.5 \\
86.5\end{array}$ \\
\hline $\begin{array}{l}\text { Day-3 } \\
\text { Present } \\
\text { Absent }\end{array}$ & $\begin{array}{l}12 \\
60\end{array}$ & $\begin{array}{l}16.7 \\
83.3\end{array}$ & $\begin{array}{l}13 \\
71\end{array}$ & $\begin{array}{l}16.5 \\
83.5\end{array}$ & $\begin{array}{c}26 \\
130\end{array}$ & $\begin{array}{l}16.7 \\
83.3\end{array}$ \\
\hline $\begin{array}{l}\text { Day-7 } \\
\text { Present } \\
\text { Absent }\end{array}$ & $\begin{array}{l}10 \\
62\end{array}$ & $\begin{array}{l}13.9 \\
86.1\end{array}$ & $\begin{array}{l}13 \\
71\end{array}$ & $\begin{array}{l}16.5 \\
83.5\end{array}$ & $\begin{array}{c}23 \\
133\end{array}$ & $\begin{array}{l}14.8 \\
85.2\end{array}$ \\
\hline Table & & te & & PE & & \\
\hline
\end{tabular}

\begin{tabular}{|c|c|c|c|c|c|c|}
\hline \multirow{2}{*}{$\begin{array}{c}\text { Peri-PEG } \\
\text { Erythema/ } \\
\text { tenderness }\end{array}$} & \multicolumn{2}{|c|}{ Group A } & \multicolumn{2}{|c|}{ Group B } & \multicolumn{2}{|c|}{ Group B } \\
\hline & \multicolumn{2}{|c|}{ N $\%$} & \multicolumn{2}{|c|}{ N \% } & \multicolumn{2}{|c|}{ N \% } \\
\hline $\begin{array}{l}\text { Day-1 } \\
\text { Present } \\
\text { Absent }\end{array}$ & $\begin{array}{c}0 \\
72\end{array}$ & $\begin{array}{c}0 \\
100\end{array}$ & $\begin{array}{c}0 \\
84\end{array}$ & $\begin{array}{c}0 \\
100\end{array}$ & $\begin{array}{c}0 \\
156\end{array}$ & $\begin{array}{c}0 \\
100\end{array}$ \\
\hline $\begin{array}{l}\text { Day-3 } \\
\text { Present } \\
\text { Absent }\end{array}$ & $\begin{array}{l}05 \\
67\end{array}$ & $\begin{array}{l}06.8 \\
90,5\end{array}$ & $\begin{array}{l}05 \\
79\end{array}$ & $\begin{array}{l}06.0 \\
94.0\end{array}$ & $\begin{array}{c}10 \\
146\end{array}$ & $\begin{array}{l}06.4 \\
93.6\end{array}$ \\
\hline $\begin{array}{l}\text { Day-7 } \\
\text { Present } \\
\text { Absent }\end{array}$ & $\begin{array}{l}07 \\
65\end{array}$ & $\begin{array}{l}09.7 \\
90.3\end{array}$ & $\begin{array}{l}08 \\
76\end{array}$ & $\begin{array}{l}09.6 \\
90.4\end{array}$ & $\begin{array}{c}15 \\
141\end{array}$ & $\begin{array}{l}08.6 \\
90.4\end{array}$ \\
\hline \multicolumn{7}{|c|}{$\begin{array}{l}\text { Table-II. Assessment of Purulent discharge after PEG } \\
\text { tube insertion }\end{array}$} \\
\hline $\begin{array}{l}\text { Peri-PEG } \\
\text { Erythema/ } \\
\text { tenderness }\end{array}$ & \multicolumn{2}{|c|}{ Group A } & Group B & $\begin{array}{c}\text { up } B \\
\%\end{array}$ & \multicolumn{2}{|c|}{ Group B } \\
\hline $\begin{array}{l}\text { Day-1 } \\
>38.5 \\
<38.5\end{array}$ & $\begin{array}{l}03 \\
69\end{array}$ & $\begin{array}{l}05.5 \\
94.5\end{array}$ & $\begin{array}{l}08 \\
76\end{array}$ & $\begin{array}{l}09.5 \\
90.5\end{array}$ & $\begin{array}{c}11 \\
145\end{array}$ & $\begin{array}{l}07.6 \\
92.4\end{array}$ \\
\hline $\begin{array}{l}\text { Day-3 } \\
>38.5 \\
<38.5\end{array}$ & 0963 & $\begin{array}{l}12.7 \\
87.3\end{array}$ & $\begin{array}{l}14 \\
70\end{array}$ & $\begin{array}{l}16.7 \\
83.3\end{array}$ & $\begin{array}{c}23 \\
133\end{array}$ & $\begin{array}{l}14.8 \\
85.2\end{array}$ \\
\hline $\begin{array}{l}\text { Day-7 } \\
>38.5 \\
<38.5\end{array}$ & $\begin{array}{l}08 \\
64\end{array}$ & $\begin{array}{l}11.1 \\
88.9\end{array}$ & $\begin{array}{l}08 \\
76\end{array}$ & $\begin{array}{l}08.5 \\
90.5\end{array}$ & $\begin{array}{c}16 \\
140\end{array}$ & $\begin{array}{l}10.3 \\
89.7\end{array}$ \\
\hline
\end{tabular}

\begin{tabular}{|c|c|c|c|c|c|c|}
\hline \multirow{2}{*}{$\begin{array}{c}\text { TLC } / \mathrm{mcL} \\
\text { Day-1 } \\
>11000\end{array}$} & \multicolumn{2}{|c|}{ Group A } & \multicolumn{2}{|c|}{ Group B } & \multicolumn{2}{|c|}{ Group B } \\
\hline & \multicolumn{2}{|c|}{$\mathbf{N} \quad \%$} & \multicolumn{2}{|c|}{$\mathbf{N} \quad \%$} & \multicolumn{2}{|c|}{ N \% } \\
\hline $\begin{array}{c}\text { Day-1 } \\
>11000 \\
\text { or }<4000 \\
4000-11000\end{array}$ & $\begin{array}{l}06 \\
66\end{array}$ & $\begin{array}{l}08.3 \\
91.7\end{array}$ & $\begin{array}{l}14 \\
70\end{array}$ & $\begin{array}{l}16.7 \\
83.3\end{array}$ & $\begin{array}{c}20 \\
136\end{array}$ & $\begin{array}{l}12.9 \\
87.1\end{array}$ \\
\hline $\begin{array}{c}\text { Day-3 } \\
>11000 \\
\text { or }<4000 \\
4000-11000\end{array}$ & $\begin{array}{l}10 \\
62\end{array}$ & $\begin{array}{l}14.0 \\
86.0\end{array}$ & $\begin{array}{l}10 \\
74\end{array}$ & $\begin{array}{l}11.6 \\
88.4\end{array}$ & $\begin{array}{c}20 \\
136\end{array}$ & $\begin{array}{l}13.0 \\
87.0\end{array}$ \\
\hline $\begin{array}{c}\text { Day-7 } \\
>11000 \\
\text { or }<4000 \\
4000-11000\end{array}$ & $\begin{array}{l}11 \\
61\end{array}$ & $\begin{array}{l}15.3 \\
84.7\end{array}$ & $\begin{array}{l}10 \\
74\end{array}$ & $\begin{array}{l}11.9 \\
88.1\end{array}$ & $\begin{array}{c}21 \\
135\end{array}$ & $\begin{array}{l}13.5 \\
86.5\end{array}$ \\
\hline
\end{tabular}




\begin{tabular}{|c|c|c|c|c|c|c|}
\hline \multirow{3}{*}{$\begin{array}{c}\text { FFICACY } \\
\text { Yes } \\
\text { No }\end{array}$} & \multicolumn{2}{|c|}{ Group A } & \multicolumn{2}{|c|}{ Group B } & \multicolumn{2}{|c|}{ Total } \\
\hline & & \multicolumn{2}{|c|}{$\mathbf{N} \quad \%$} & \multicolumn{2}{|c|}{ N $\%$} \\
\hline & 6111 & $\begin{array}{l}84.7 \\
15.3\end{array}$ & 6611 & $\begin{array}{l}78.6 \\
21.4\end{array}$ & $\begin{array}{c}127 \\
29\end{array}$ & $\begin{array}{l}81.4 \\
18.6\end{array}$ \\
\hline$\%^{2}$ value & 0963 & $\begin{array}{l}12.7 \\
87.3\end{array}$ & $\begin{array}{l}14 \\
70\end{array}$ & $\begin{array}{l}16.7 \\
83.3\end{array}$ & $\begin{array}{c}23 \\
133\end{array}$ & $\begin{array}{l}14.8 \\
85.2\end{array}$ \\
\hline Total & \multicolumn{2}{|c|}{$34.72 * * \star$} & \multicolumn{2}{|c|}{$27.47^{\star \star \star}$} & & \\
\hline
\end{tabular}

Table-V. Assessment of efficacy of antibiotics *** $P, 001$

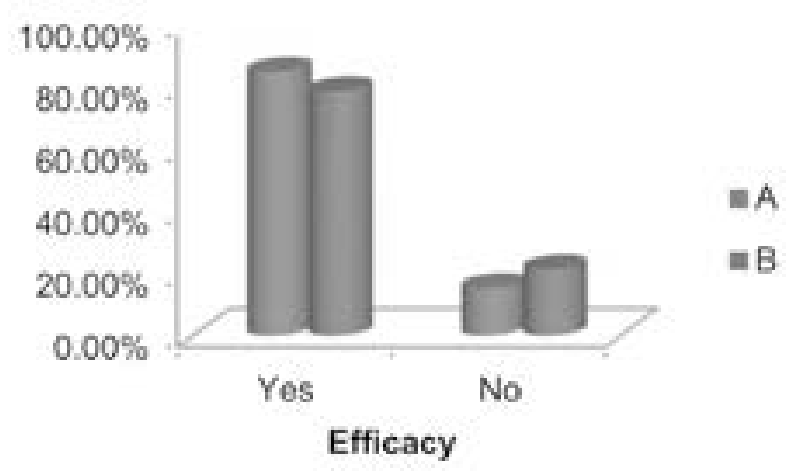

Figure-1. Assessment of efficacy of antibiotics

\section{DISCUSSION}

Our study shows that antibiotic prophylaxis with either Cephalexin or Co-amoxiclav reduces the infection after percutaneous endoscopic gastrostomy and there is no significant statistical difference between the efficacy of both the antibiotics. The study was quite a large study of antibiotic prophylaxis in PEG tube placement. This is the first study to compare two antibiotics for prophylaxis of peristomal infection. It showed similar results in efficacy of Co-amoxiclave in PEG prophylaxis as in previous study. ${ }^{12}$ However Cephalexin efficacy was $84.7 \%$ as compared to $93.8 \%$ in previous study of Cephalexin vs. Cefdinir in controlling skin infection. ${ }^{13}$ This study was carried out at a cancer centre and almost all patients were having malignancy, mostly having head and neck cancer. Malignancy has previously been associated with an increased risk of complication after percutaneous endoscopic gastrostomy. ${ }^{14}$ Other studies indicate that patients with neurological diseases may be more prone to infection than patients with cancer. ${ }^{4}$ This factor of immunocompromise state in cancer patients may explain the lower efficacy results of Cephalexin as compared to previous ones. Several previous studies noted a high risk of infectious complications.

In a previous study in which over half of the patients were having the cancer overall incidence of infection after percutaneous endoscopic gastrostomy was $42 \% .^{7}$

G.Perlick et al. studied that single prophylactic dose of $2.2 \mathrm{~g}$ of co-amoxiclav had efficacy of around $80 \%$ by preventing peristomal infection. ${ }^{12}$ While our study shows the efficacy of Co-amoxiclav slightly less i.e. $78.6 \%$.Similarly Kenneth $\mathrm{J}$ et al showed that Cephalexin had cure rate of $93.8 \%$ for treatment of skin infection in pediatric patients. ${ }^{13}$

An important area of oncology in which PEGs appear to have a relatively proven record is in patients with head and neck cancers. Head and neck cancers are commonly diagnosed when they are already in advanced stages. Aggressive chemotherapy and radiotherapy can lead to dysphagia, odynophagia, dehydration, and malnutrition, which can result in interruption of treatment and frequent hospitalization. ${ }^{15}$ These immunocompromised patients are vulnerable to any infections while on chemotherapy, so upon receiving prophylactic antibiotics, peristomal infections are reduced with reports showing better tolerance of chemo-radiation. ${ }^{8,10}$

As PEG placement is via endoscopy, there is much higher risk of having bacterial infection while doing the procedure. Highest rates of bactremia have been reported with esophageal dilatation and sclerotherapy that can be associated with so many other factors but one of them will be low immunity in preexisting liver cirrhosis. ${ }^{16}$ Doing procedures in these circumstances is wise able to prevent any future infection by giving pre procedure or post procedure antibiotics. As shown in previous data there is higher incidence of bactremia with dilatation of malignant strictures rather than benign one. ${ }^{16}$ 
Survival benefits due to feeding through PEG have been noted in certain indications for example acute stroke and prophylactic ally used in head and neck cancers but not in all like dementia. ${ }^{17}$ While survival remains multifactorial in such patients we believe that nutritional support through PEG along with pre procedural and post procedural use of antibiotics improve care conveniently.

The choice of prophylactic regimen is unlikely to account for the differing results of previous trials. In one study, three doses cefoxitin were used and found no effect on wound infection ${ }^{18}$, whereas in other study it was reported that significant protection with a single dose cefazolin ${ }^{6}$, a drug less effective against anaerobic bacteria than cefoxitin or co-amoxicalv but similarly effective against aerobic organisms from the upper gastrointestinal tract and mouth flora. ${ }^{19}$ In our study there is statistically significant data about the prevention of peri-PEG infection and statistically no antibiotic is superior to other ( $p$ value 0.325 ). It looks that giving 5 day course of either Cephalexin or Co-amoxicalv as a prophylaxis just after PEG tube insertion is more appropriate. As compared to other intravenous antibiotics, both Cephalexin and Co-amoxiclav are cheaper and easily available in the market.

As most of our patients were having cancers, they were started on chemo radio therapy immediately (on average 5-7 days) after PEG tube placement, so immunosupression at this stage may have possibly affected the overall results of this study.

Antibiotic prophylaxis before and five days after percutaneous endoscopic gastrostomy is very useful by preventing peri-stomal infection on basis of results of this study. It is well tolerated, easy to perform and reduces morbidity and the need for treatment because of infection. Our study results show that both Cephalexin and Co-amoxiclav are equally effective against prophylaxis of peristomal infection. So we recommend using any of the antibiotics, either Cephalexin or Co-amoxiclav as prophylaxis after PEG tube placement. Future studies should compare the antibiotic efficacy in different groups of patients like cancers, dementia or in stroke patients with PEG tube.

Copyright (C) 10 Dec, 2015.

\section{REFERNCES}

1. Sullivan AM, Lakoma MD, Block SD. The status of medical education in end of life care: a national report. J Gen Intern Med 2003; 18:685-695.

2. Park RH, Allison MJ, Lang J. Randomized comparison of percutaneous endoscopic gastrostomy and nasogastric tube feeding in patients with persistent neurological dysphagia. BMJ 1992; 304:1406.

3. Duszak, R Jr, Mabry MR. National trends in gastrointestinal access procedures: an analysis of Medicare services provided by radiologists and other specialists. J Vasc Interv Radiol 2003; 14:1031.

4. National Confidential Enquiry into Patient Outcome and Death. Scoping Our Practice: the 2004 Report of the National Confidential Enquiry into Patient Outcome and Death. London, 2004 (available at http:// www.ncepod.org.uk/pdf/2004/04sum.pdf, accessed 18 September 2006).

5. Anis MK, Abid S, Jafri W, Abbas Z, Shah HA, Hamid $S$. Acceptability and outcomes of the percutanous endoscopic gastrostomy (PEG) tube placementpatient's and care giver's perspectives. BMC Gastroentrol 2006; 6:37.

6. Panigrahi H, Shreeve DR, Tan WC, Prudham R, Kaufman $R$. Role of antibiotic prophylaxis for wound infection in percutaneous endoscopic gastrostomy (PEG): result of a prospective double blind randomized trial. J Hosp Infect 2002; 50: 312-5.

7. Memon S, Burney AA. An Audit of Indication and complications of Percutanous Endoscopic gastrostomy. J Liaqat Unimed health Sci 2005; 44:60-3.

8. British Society of Gastroenterology. Antibiotic Prophylaxis in Gastrointestinal Endoscopy. London, 2001

9. Saadeddin A, Freshwater DA, Fisher NC, Jones BJ. Antibiotic prophylaxis for percutaneous endoscopic gastrostomy for non-malignant conditions: a double blind prospective randomised controlled trial. Aliment Pharmacol Ther 2005; 22:565-70.

10. Ahmed I, Moncher A, Abdoolah A, Stenson R, Wright $\mathrm{J}$, Daniels $A$, et al. Antibiotic prophylaxis for percutaneous endoscopic gastrostomy: a prospective randomized double blind trial. Aliment pharmacol Ther 2003;189:47-8

11. Benjamin A, Dabney R, Frederic B, Robert D, Manuel 
$R$, Ofloxacin versus cephalexin for treating skin and soft tissue infections. Aliment Pharmacol Ther 2004; 22:585-6.

12. Perlick G, Grune S, Leser HG, Lebherz J, Heldwein W, Machka K, et al. Prospective randomized double blind trial of prophylaxis with single dose of co-amoxiclav before percutaneous endoscopic gastrostomy. British Med J 2004; 25:320

13. Kenneth J T,Constance $H$, Jeserling, James Maccarty, Heddrick JA Study of the use cefdinir versus cephalexin for treatment of skin infections in pediatric patients. Antimicrobial agents chemother 1997:41:739-742.

14. Khokhar N, Gill M L. Percutaous endoscopic gastrostomy: an eight year experience in tertiary care center in Pakistan. Pak Postgrad Med J 2003; 14:137-40

15. Ravasco P, Monteiro-Grillo I, Marques, Vidal P, Camilo ME. Impact of nutrition on outcome: a prospective randomized controlled trial in patients with head and neck cancer undergoing radiotherapy. Head Neck 2005; $27: 659$

16. Nelson DB, Sanderson SJ, Azar MM. Bactremia with esophageal dilatation. Gastrointest Endosc 2003; 48:563-7

17. Murphy LM, Lipman TO. Percutaneous endoscopic gastrostomy does not prolong survival in patients with dementia. Arch Intern Med 2003; 163:1351-3.

18. Jafri, NS, Mahid, SS, Minor, KS, et al. Meta-analysis: antibiotic prophylaxis to prevent peristomal infection following percutaneous endoscopic gastrostomy. Aliment Pharmacol Ther 2007; 25:647.

19. Chaudhary KA, Smith OJ, Cuddy PG, Clarkston WK. PEG site infections: The emergence of methicillin resistant Staphylococcus aureus as a major pathogen. Am J Gastroenterol 2002; 97:1713.

20. Kobayashi K, Cooper GS, Chak A. A prospective evaluation of outcome in patients referred for PEG placement. Gastrointest Endosc 2002; 55:500.

21. Lynch CR, Fang JC. Prevention and management of complications of percutaneous endoscopic gastrostomy (PEG) tubes. Nutrition Issues in Gastroenterology series \#22. Pract Gastroenterol J 2004; 66-76

22. Monteleoni C, Clark E. Using rapid-cycle quality improvement methodology to reduce feeding tubes in patients with advanced dementia: before and after study. BMJ 2004; 329: 491-4.

23. Walters G, Ramesh P, Memon MI. Buried Bumper Syndrome complicated by intra-abdominal sepsis. Age and ageing 2005; 34: 650-1.

24. Medline plus; a service of U.S. National Library of Medicine and the National Institute of Health 2009.

25. Jafri NS, Mahid SS, Minor KS. Meta-analysis: antibiotic prophylaxis to prevent peristomal infection following percutaneous endoscopic gastrostomy. Aliment Pharmacol Ther 2007; 25:647

\section{AUTHORSHIP AND CONTRIBUTION DECLARATION}

\begin{tabular}{|c|c|c|c|}
\hline Sr. \# & Author-s Full Name & Contribution to the paper & Author $=\mathbf{s}$ Signature \\
\hline 1 & Dr. Sajid Hussain & Research & \\
\hline 2 & Dr. Kashif Ali & Compiling, Editing \& & \\
\hline 3 & Dr. Hafiz M. Farhan Rashid & $\begin{array}{l}\text { Compiling, Editing \& } \\
\text { Analysis }\end{array}$ & \\
\hline 4 & Dr. Abrar Hussain Khosa & Data Collection & \\
\hline 5 & Dr. Aushter Abbas & & \\
\hline
\end{tabular}

